\title{
PEMANFAATAN GALERI VIRTUAL SEBAGAI MEDIA PROMOSI WISATA KABUPATEN LANDAK
}

\section{THE UTILIZATION OF THE VIRTUAL GALLERY AS A MEDIA FOR HISTORICAL TOURISM PROMOTION OF KABUPATEN LANDAK}

\author{
Sulistiowati $^{1 *}$, Nurul Komari ${ }^{2}$, Sri Kurniawati ${ }^{3}$ Ilzar Daud $^{4}$ \\ (Fakultas Ekonomi dan Bisnis, Universitas Tanjungpura, Indonesia) \\ 1'sulistiowati@ekonomi.untan.ac.id; ${ }^{2}$ komari_nurul@yahoo.com; ${ }^{3}$ sri.kurniawati@ekonomi.untan.ac.id; \\ ${ }^{4}$ ilzar_daud@yahoo.com
}

\begin{abstract}
Abstrak
Kegiatan Pengabdian Kepada Masyarakat ini dilakukan di Kabupaten Landak, Propinsi Kalimantan Barat. Tujuan dari kegiatan ini adalah membantu masyarakat Kabupaten Landak untuk mengoptimalkan promosi pariwisata agar dapat dikenal oleh masyarakat luas, bahkan sampai ke manca negara. Metode yang digunakan adalah focus group discussion dan pelatihan. Kegiatan ini terdiri dari tiga tahapan, yaitu tahap persiapan, tahap pelaksanaan, dan tahap evaluasi. Hasil kegiatan PkM ini adalah sebuah galeri virtual wisata eksotis Kabupaten Landak yang dapat menginformasikan kepada khalayak luas tentang pariwisata di Kabupaten Landak.
\end{abstract}

Kata Kunci; Landak; Galeri Virtual ; Pariwisata

\begin{abstract}
Community Service is carried out in Landak Regency, West Kalimantan Province. The purpose of this activity is to help the people of Landak Regency to optimize tourism promotion so that it can be recognized by the wider community, even to foreign countries. The method used was focus group discussion and training. This activity consists of three stages, namely the preparation stage, the implementation stage, and the evaluation stage. The result of this activity is a virtual gallery of exotic tourism in Landak Regency which can inform a wide audience about tourism in Landak Regency.
\end{abstract}

Keywords; Landak Regency, virtual gallery, tourism.

\section{PENDAHULUAN}

Pariwisata adalah serangkaian kegiatan perjalanan yang dilakukan oleh perorangan atau keluarga ataun kelompok dari tempat tinggal asalnya ke berbagai tempat lain dengan tujuan melakukan kunjungan wisata dan bukan untuk bekerja atau mencari penghasilan di tempat tujuan (Soedarso et al., 2014). Cohen (1974) menjabarkan bahwa dampak sosial ekonomi pariwisata terhadap masyarakat lokal secara garis besar dapat dikatagorikan dalam delapan kelompok besar, yaitu: dampak terhadap penerimaan devisa, dampak terhadap pendapatan masyarakat, dampak terhadap kesempatan kerja, dampak terhadap harga-harga, dampak terhadap distribusi manfaat atau keuntungan, dampak terhadap kepemilikan dan kontrol, dampak terhadap pembangunan umum, dan dampak terhadap pendapatan pemerintah. 
Dalam sistem pariwisata, ada banyak pihak yang berperan dalam menggerakkan sistem. Pihak-pihak tersebut adalah insan-insan pariwisata yang ada pada berbagai sektor. Secara umum, pariwisata dikelompokkan dalam tiga pilar utama, yaitu (1) masyarakat, (2) swasta, (3) pemerintah. Yang termasuk masyarakat adalah masyarakat umum yang ada pada destinasi, sebagai pemilik dari berbagai sumber daya yang merupakan modal pariwisata, seperti kebudayaan. Termasuk ke dalam kelompok masyarakat ini juga tokoh-tokoh masyarakat, intelektual, LSM, dan media massa. Selanjutnya, dalam kelompok swasta adalah asosiasi usaha pariwisata dan para pengusaha, sedangkan kelompok pemerintah adalah berbagai wilayah administrasi, mulai dari pemerintah pusat, provinsi, kabupaten, kecamatan, dan seterusnya (Prasetya dan Rani, 2014).

Dari berbagai objek wisata di Kalimantan Barat, Makam Juang Mandor adalah salah satu yang populer. Makam Juang Mandor merupakan memorial atas terjadinya Tragedi Mandor Berdarah DPRD Kalimantan Barat mengeluarkan Perda Nomor 5 Tahun 2007 tentang Peristiwa Mandor sehingga tanggal 28 Juni ditetapkan sebagai Hari Berkabung Daerah Kalimantan Barat. Selain makam, terdapat monumen dan relief yang menggambarkan sejarah perjuangan rakyat Mandor. Lokasi wisata sejarah Juang Mandor memakan waktu tempuh sekitar 1,5 jam dari Kota Pontianak yang merupakan Ibu Kota Propinsi Kalimantan Barat. Sepanjang jalan menuju lokasi terdapat pemandangan alam yang asri speerti sawah, ladang dan perkebunan. Selain wisata sejarah tersebut, keunggulan lainnya di Kabupaten Landak dapat menjadi objek wisata pendukung bagi wisatawan yang berkunjung ke Monumen Juang Mandor, seperti atraksi budaya, kerajinan daerah, dan produk kuliner yang dapat dijadikan buah tangan bagi wisatawan.

Dari hasil survey Tim Pengabdian kepada Masyarakat Fakultas Ekonomi dan Bisnis Univarsitas Tanjungpura, potensi wisata yang terdapat Kabupaten Landak Propinsi Kalimantan Barat adalah:

1. Potensi wisata Sejarah; yaitu adanya monumen dan makam juang mandor.

2. Potensi wisata alam: Rombo Terintik, Air Terjun Dait, Air Terjun Ringin, Riam Bedawan, Air Terjun Angan Tembawang, Goa Sanjan, Air Terjun Ampar Jawa

3. Potensi wisata budaya; yaitu adanya Rumah Panjang, upacara adat penyimpanan benih Naik Dango, Festival Budaya Binua Landak, Tumpang Negeri dan Ziarah Akbar, serta tradisi budaya Robo'-Robo'. 
4. Potensi wisata kerajinan: tudung saji, ukiran kayu, tas dari kulit kayu, keranjang buah berbahan rotan .

5. Potensi wisata kuliner: Kue Kap, gula semut, gula aren, buah-buahan.

Jika dibandingkan dengan wisata sejarah di daerah maupun di negara lain, pengelolaan wisata sejarah Monumen Juang Mandor masih jauh tertinggal. Selain pengelolaan fasilitas wisata, promosi juga tidak begitu gencar dilakukan. Peran serta masyarakat juga diperlukan terutama untuk masyarakat disekitar obyek wisata. masyarakat dapat mengembangkan ekonomi kreatif seperti kerajinan untuk souvenir dan kuliner khas untuk oleh-oleh. Dengan berkembangnya sektor pariwisata, perekonomian masyarakat sekitar akan meningkat.

Adanya pandemi Covid-19 menyebabkan kegiatan orientasi yang seharusnya dilaksanakan di Kecamatan Mandor dialihkan menjadi kegiatan webinar. Webinar FGD dengan Pemerintah Kabupaten Landak membicarakan tentang konsep wisata yang dapat dikembangkan di Kabupaten Landak, Kegiatan diikuti oleh Tim PkM FEB UNTAN dan jajaran SKPD kabupaten Landak, termasuk Bupati Landak, dr. Karolin Margret Natasha. Pemerintah Daerah, terutama Bupati menyambut baik rancangan kegiatan PkM ini.

Dari webinar tersebut disimpulkan bahwa permasalahan yang dihadapi masyarakat Kabupaten Landak dalam mengoptimalkan potensi wisata di daerahnya adalah belum meluasnya informasi yang jelas dan akurat tentang wisata di Kabupaten Landak. Tanpa promosi, masyarakat luas tidak akan mengetahui potensi wisata terbaik sekalipun yang ada di daerah tertentu. Perlu adanya galeri virtual yang dapat diakses dari mana saja sebagai upaya memperkenalkan potensi wisata kepada masyarakat luas. Prioritas permasalahan yang dibantu melalui kegiatan Pengabdian kepada Masyarakat ini adalah:

1. Permasalahan dalam kegiatan promosi melalui pemanfaatan teknologi informasi yang belum dilakukan.

2. Permasalahan peningkatan kemampuan sumber daya manusia dalam mengelola promosi wisata Kabupaten Landak.

3. Permasalahan dalam penjualan kerajinan khas Kabupanten Landak.

Permasalahan dalam mengembangkan potensi pariwisata di Kabupaten Landak adalah kurangnya media promosi agar calon wisatawan dari berbagai penjuru paling tidak mengetahui bahwa ada beragam objek wisata di Kabupaten Landak. Cara yang paling mudah dan dapat menjangkau target yang lebih luas adalah dengan promosi melalui media internet 
(Li dan Yang, 2014). Internet adalah jaringan computer yang saling terhubung yang dapat menggunakan berbagai macam layanan yang tersedia, yang berisi informasi - informasi yang diinginkan pagi penggunanya.

Menurut Kuryanti dan Indriani (2018) Informasi-informasi yang diberikan oleh sebuah website haruslah memenuhi kriteria informasi yang baik, seperti : (a) Ketersediaan; Informasi yang diberikan harus dapat diperoleh bagi orang yang ingin memanfaatkannya. (b) Mudah dipahami; Informasi yang diberikan harus mudah dipahami bagi orang yang ingin menggunakannya. (c) Relevan; Informasi yang diberikan haruslah relevan dengan permasalahan yang ada. (d) Bermanfaat; Informasi yang diberikan haruslah bermanfaat bagi pengguna informasi tersebut. (e) Tepat waktu; Informasi yang diberikan haruslah tepat waktu pada situasi yang diperlukan. (f) Keandalan; Informasi yang diberikan haruslah didapat dari sumber yang dapat diandalkan kebenarannya. (g) Akurat; Informasi yang diberikan haruslah bebas dari kesalahan dan kekeliruan, dan (h) Konsisten; Informasi yang diberikan tidak boleh mengandung kontradiksi dalam penyajiannya.

Promosi pariwisata lewat unternet dapat dilakukan dengan membuat galeri virtual. Galeri virtual adalah galeri yang dapat diakses melalui media internet, sehingga dapat mencakup audiens yang lebih luas. Pembuatan galeri virtual dimulai dengan mengumpulkan bahan-bahan yang akan mengisi galeri tersebut, yaitu berupa foto-foto objek wisata beserta deskripsinya, serta produk-produk khas Kabupaten Landak, dimana pada galeri tersebut dibuat marketplace penjualan produk. Berdasarkan permasalahan tersebut, maka solusi yang ditawarkan dalam kegiatan PkM ini tercantum pada Tabel 1.

Tabel 1. Solusi dan Target Luaran

\begin{tabular}{|l|l|l|}
\hline \multicolumn{1}{|c|}{ Permasalahan } & \multicolumn{1}{|c|}{ Solusi } & \multicolumn{1}{c|}{ Luaran } \\
\hline $\begin{array}{l}\text { Permasalahan dalam kegiatan } \\
\text { promosi melalui pemanfaatan } \\
\text { teknologi informasi yang } \\
\text { belum dilakukan. }\end{array}$ & $\begin{array}{l}\text { Membuat galeri virtual. } \\
\text { Melatih administrator galeri } \\
\text { virtual. }\end{array}$ & $\begin{array}{l}\text { Sebuah galeri virtual. } \\
\text { 2 orang administrator galeri } \\
\text { virtual. }\end{array}$ \\
\hline $\begin{array}{l}\text { Permasalahan peningkatan } \\
\text { kemampuan sumber daya } \\
\text { manusia dalam mengelola } \\
\text { promosi wisata Kabupaten } \\
\text { Landak. }\end{array}$ & $\begin{array}{l}\text { Melatih keterampilan } \\
\text { fotografi. } \\
\text { Melatih keterampilan } \\
\text { menuliskan deskripsi objek } \\
\text { wisata yang menarik }\end{array}$ & $\begin{array}{l}\text { 4 orang pengelola galeri virtual } \\
\text { mampu menuliskan deskripsi } \\
\text { objek wisata yang menarik. } \\
\text { Foto-foto objek wisata yang } \\
\text { menarik. }\end{array}$ \\
\hline $\begin{array}{l}\text { Permasalahan dalam penjualan } \\
\text { kerajinan khas Kabupanten } \\
\text { Landak. }\end{array}$ & $\begin{array}{l}\text { Membuat marketplace produk } \\
\text { khas daerah. }\end{array}$ & $\begin{array}{l}\text { Marketplace sebagai bagian } \\
\text { dari galeri virtual. }\end{array}$ \\
\hline
\end{tabular}


Menurut (Albarq, 2013), minat berkunjung wisatawan berarti sama dengan minat pembelian. Dalam dimensi pemasaran minat beli akan dipengaruhi oleh stimulus-stimulus serta perasaan positif terhadap suatu produk atau biasa disebut persepsi positif. Persepsi positif dapat muncul karena stimulus dari promosi pariwisata. Promosi pariwisata dapat dilakukan melalui media internet. Mayoritas wisatawan akan mencari rekomendasi destinasi wisata melalui internet. Selain itu internet lebih luas cakupannya dan berbiaya lebih murah daripada media lainnya.

Menurut (Mcphead, 2011), internet lebih dari sekadar meletakkan informasi di web. Mempromosikan pariwisata melalui media online membutuhkan strategi yang mengintegrasikan aktivitas online dan offline. Penelitian terdahulu menyimpulkan promosi lewat internet membantu kemajuan pariwisata. Di Ethiopia, promosi lewat internet memberikan kontribusi tertinggi bagi pariwisata dibanding media lain (Mekonen, 2016). Promosi pariwisata melalui Internet membantu menyebarkan informasi tentang penawaran pariwisata, sehingga pengembangan promosi pariwisata melalui Internet harus dilanjutkan untuk mencapat benefit yang optimal (Alsarayreh et al., 2011). Tujuan kegiatan pengabdian kepada masyarkaat ini adalah membantu masyarakat Kabupaten Landak untuk mempromosikan objek-objek wisata yang ada, terutama wisata sejarah Juang Mandor, sehingga pariwisata di Kabupaten Landak dapat dikenal oleh masyarkat luas terutama calon wisatawan, dan pada akhirnya menjadikan Kabupaten Landak sebagai salah satu destinasi wisata mereka.

\section{METODOLOGI}

Pendekatan yang digunakan dalam kegiatan pengabdian kepada masyarakat ini adalah focus group discussion dan pelatihan. Sedangkan tahapan yang dilakuan adalah tahap persiapan, pelaksanaan, dan evaluasi.

\section{Tahap persiapan.}

Pada tahap persiapan, tim melakukan orientasi, yaitu survey ke masyarakat dan melaksanakan focus group discussion dengan Dinas Kepemudaan, Olah Raga dan Pariwisata serta Dinas Koperasi, Usaha Mikro Kecil dan Menengah, Perindustrian dan Perdagangan Kabupaten Landak, untuk mengidentifikasi materi kebutuhan promosi wisata Kabupaten Landak, dan mengidentifikasi kemampuan staf administrasi yang akan menangani galeri virtual. 


\section{Tahap pelaksanaan.}

Pada tahap pelaksanaan, kegiatan yang dilakukan adalah pembuatan galeri virtual, pelatihan administrator galeri virtual, pelatihan fotografi, pelatihan penulisan deskripsi objek wisata yang menarik, serta pembuatan marketplace yang merupakan bagian dari galeri virtual.

\section{Tahap evaluasi}

Pada tahap evaluasi dilakukan penilaian keberhasilan kegiatan pelatihan dan hasil pembuatan galeri virtual dan market place.

Target sasaran kegiatan PkM adalah Dinas Koperasi, Usaha Kecil Menengah, Perindustruan dan Perdagangan; serta Dinas Pemuda, Olah Raga, dan Pariwisata Kabupaten Landak Propinsi Kalimantan Barat.Kegiatan Focus Group discussion dilaksanakan pada tanggal 25 Juli 2020 di Aula Dinas Pemuda, Olah Raga dan Pariwisata Kabupaten Landak. Pelatihan membuat galeri virtual, fotografi dan membuat produk khas daerah dilaksanakan pada tanggal 13 Agustus 2020 di Rumah Radakng Aya, Kampung Wisata Kabupaten Landak.

\section{PEMBAHASAN}

Pelaksanaan kegiatan Pengabdian Kepada Masyarakat berjalan lancar. Pada tanggal 25 Juli 2020 dilaksanakan focus group discussion dengan tokoh masyarakat dan pejabat pada Dinas Koperasi, Usaha Kecil Menengah, Perindustruan dan Perdagangan; serta Dinas Pemuda, Olah Raga, dan Pariwisata Kabupaten Landak Propinsi Kalimantan Barat. Hasip FGD menyimpulkan bahwa perlu tindakan nyata dalam upaya mengenalkan potensi pariwisata kabupaten Landak kepada masyarakat luas dan menyetujui pembuatan galeri virtual yang akan menjadi media promosi wisata Kabupaten Landak.

Pelaksanaan pelatihan membuat galeri virtual, fotografi dan membuat marketplace produk khas daerah dilaksanakan pada tanggal 13 Agustus 2020 yang bertempat di Rumah Radakng Aya Kabupaten Landak. Peserta pelatihan adalah anggota masyarakat aktivis pariwisata yang ditunjuk oleh Dinas Pemuda, Olah Raga, dan Pariwisata Kabupaten Landak.

Dalam pelatihan membuat galeri virtual, peserta dilatih untuk mendeskripsikan objekobjek wisata dengan baik dan jelas, menyisipkan foto-foto dengan rapi, serta membuar supaya galeri tersebut mudah dipahami. Pelatihan fotografi mengajarkan peserta untuk mengambil gambar objek wisata supaya menarik bagi pengunjung galeri virtual. Pelatihan 
membuat merketplace produk khas daerah mengajarkan para peserta membuat deskripsi produk yang menarik dan memilih foto-foto yang baik supaya produk terlihat nyata bagi pengunjung galeri virtual.

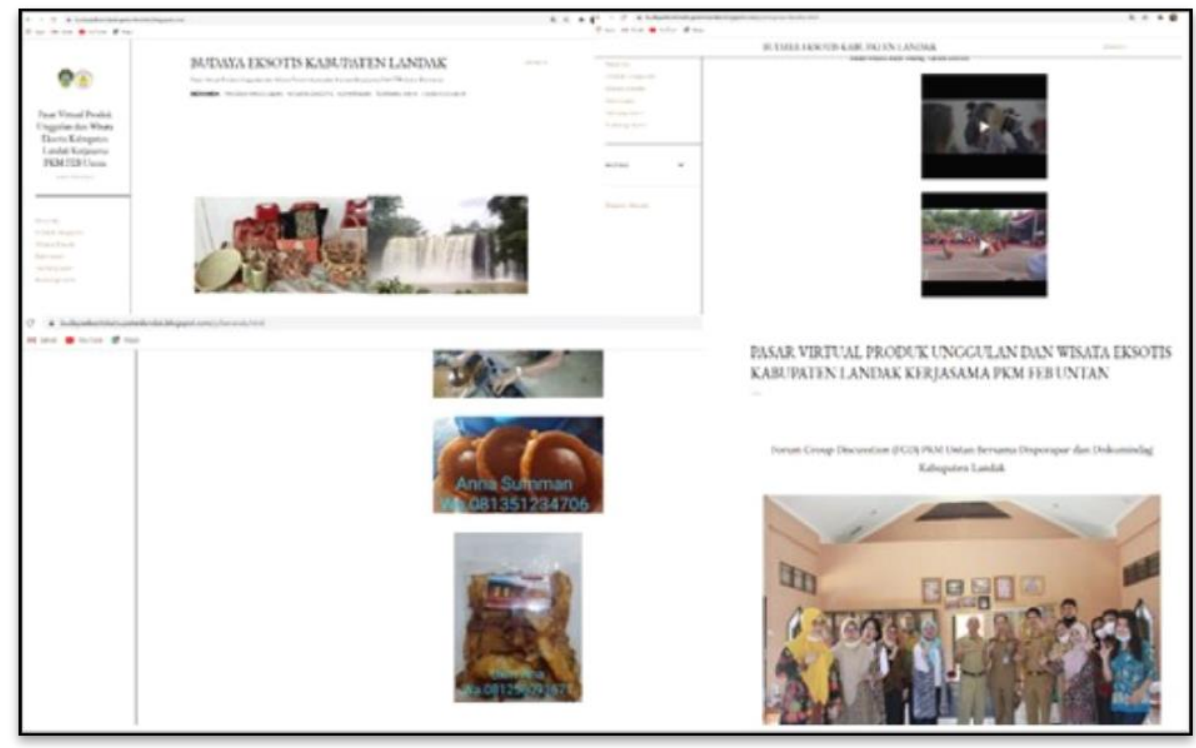

Figur 1. Galeri Virtual Kabupaten Landak

Peserta menyambut baik dan antusias dalam mengikuti pelatihan membuat galeri virtual, fotografi dan membuat marketplace produk khas daerah. Peserta beranggapan pelatihan tersebut sangat bermanfaat karena merupakan ilmu baru yang mereka terima dan dapat diterapkan untuk meningkatkan promosi pariwisata di Kabupaten Landak. Kendala yang dihadapi dalam kegiatan PkM ini adalah sinyal internet yang kurang baik saat pelatihan dilakukan sehingga pelatihan dilaksanakan dalam waktu yang lebih lama dari rencana.

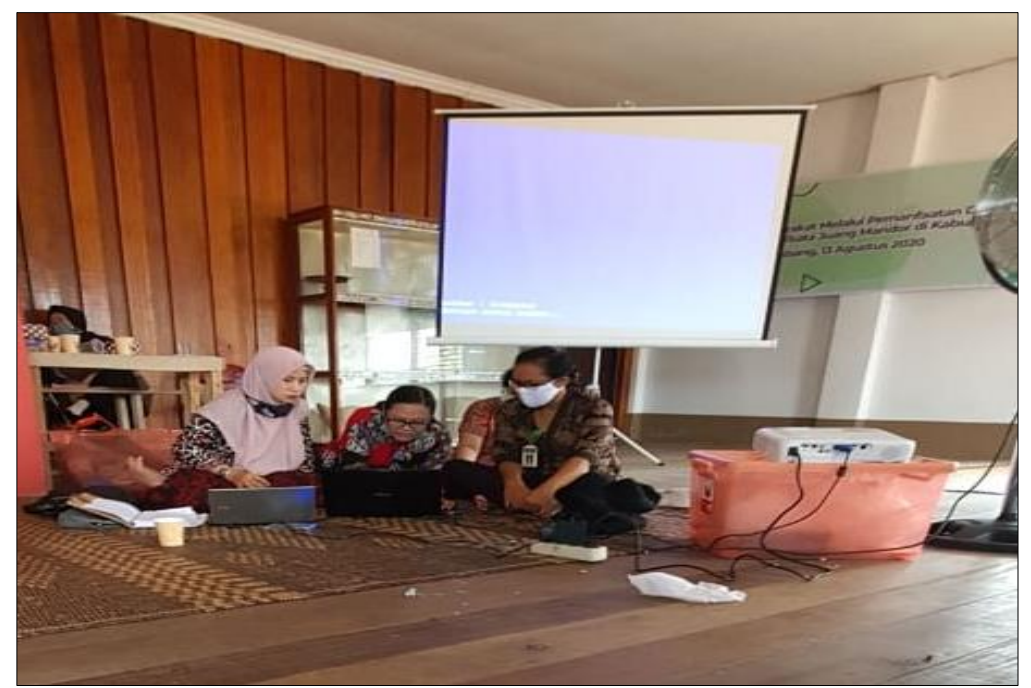

Figur 2. Pelatihan administrator Galeri Virtual 
Luaran yang dihasilkan dari kegiatan PkM ini adalah Sebuah galeri virtual dengan marketplace produk khas Kabupaten Landak di dalamnya, dua orang administrator galeri virtual, empat orang pengelola galeri virtual yang mampu menuliskan deskripsi objek wisata yang menarik, serta foto-foto objek wisata yang menarik. Galeri virtual beralamat https://budayaeksotiskabupatenlandak.blogspot.com. Halaman utama adalah Tema galeri virtual dan identitas. Terdapat 6 (enam) halaman utama pada galeri virtual ini, yaitu beranda, produk unggulan, wisata eksotis, kemitraan, tentang kami, dan hubungi kami.

\section{KESIMPULAN DAN SARAN}

Kegiatan pengabdian kepada masyarakat ini mencoba memanfaatkan galeri virtual untuk memperluas promosi pariwisata di Kabupaten Landak. Untuk mendukung keberhasilan promosi virtual kegiatan yang dilakukan antara lain membuat galeri virtual dan market place produk khas daerah, pelatihan administrator galeri virtual, pelatihan fotografi, dan pelatihan penulisan deskripsi objek wisata yang menarik. Harapan selanjutnya galeri virtual wisata eksotis Kabupaten Landak dapat selalu diperbaharui dengan informasi terbaru sehingga mendeskripsikan kondisi terkini dari objek wisata di Kabupaten Landak. Evaluasi keberhasilan masih memerlukan waktu untuk mengukur efektivitas galeri virtual tersebut, namun paling tidak ada sumber informasi yang akurat yang dapat memberikan pilihan bagi calon wisatawan dalam menentukan destinasi wisata, yang diharapkan akan memilih Kabupaten Landak. Saran yang dapat diberikan untuk kegiatan pengabdian kepada mayarakat selanjutnya adalah fokus pada fasilitas-fasilitas pendukung pariwisata yang merupakan pertimbangan bagi wisatawan dalam memilih tujuan wisata.

\section{REFERENSI}

Albarq, A. N. (2013). Measuring the Impacts of Online Word-of-Mouth on Tourists' Attitude and Intentions to Visit Jordan: An Empirical Study. International Business Research, 7(1): 14-22. https://doi.org/10.5539/ibr.v7n1p14

Alsarayreh, M. N., Jawabreh, O. A. A., Alkharabsheh, K. S., dan Aldahamsheh, M. M. (2011). Tourism promotion through the internet (Websites) (Jordan as a case study). Asian Social Science, 7(6): 125-135. https://doi.org/10.5539/ass.v7n6p125

Cohen, E. (1974). Who Is A Tourist? A Conceptual Clarification. The Sociological Review. The Heberw University. 
Gunardi, G. (2010). Identifikasi Potensi Kawasan Wisata Kali Pasir, Kota Tangerang. Planesa, 1(1): 28-35.

Harjoseputro, Y., dan Herawati, F. A. (2018). Pemanfaatan Website sebagai Media Promosi Kampung Wisata Rejowinangun dan Pakualaman, Yogyakarta. Prosiding Seminar Nasional Hasil Pengabdian Kepada Masyarakat (SENDIMAS), 3(October), 77-82.

Kuryanti, S. J., dan Indriani, N. (2018). Pembuatan Website Sebagai Sarana Promosi Pariwisata. Jurnal \& Penelitian Teknik Informatika, 2(2): 37-46.

Li, Y., dan Yang, R. (2014). New Business Model for Company to Win the Competition. American Journal of Industrial and Business Management, 4: 190-198.

Mcphead, S. (2011). Developing an internet marketing strategy: internet marketing academy and Ventus publishing Aps. Downloaded the free book at bookboon.com. Available at: www.internetmarketingacademy.comlast

Mekonen, T. A. (2016). The role of media in tourism promotion: A case study in Ethiopia. Journal of Hospitality Management and Tourism, 7(5): 50-56. https://doi.org/10.5897/jhmt2016.0177

Pitana, I.G. dan Gayatri. G. (2005). Sosiologi Pariwisata. Jogjakarta. Andi.

Prasetya, D., dan Rani, M. (2014). Pengembangan Potensi Pariwisata Kabupaten Sumenep, Madura, Jawa Timur (Studi Kasus: Pantai Lombang). Jurnal Politik Muda, 3(3): 412421.

Soedarso, Nurif, M., dan Windiani. (2014). Potensi Dan Kendala Pengembangan Pariwisata Berbasis Kekayaan Alam Dengan Pendekatan Marketing Places (Studi Kasus Pengembangan Pariwisata Di Kabupaten Bojonegoro). Jurnal Sosial Humaniora, 7(2): 136-149. 